\title{
Peminggiran Jemaat Ahmadiyah Indonesia (JAI) dan Penyesuaian Tindakan Sosialnya
}

\author{
Catur Wahyudi \\ Dosen FISIP Universitas Merdeka Malang
}

\begin{abstract}
Abstrak
Artikel ini mengungkap peminggiran Jemaat Ahmadiyah Indonesia (JAI) atau Ahmadiyah Qadiyani di Indonesia dan penyesuaian tindakan sosialnya, khususnya pada masa pemerintahan era reformasi. Penyesuaian tindakan sosial JAI ditunjukkan dengan serangkaian realitas, yaitu : (1) dasar keyakinan yang kokoh dalam situasi tertekan sekalipun tidak pernah menjadikan eksistensinya melemah; (2) peminggiran yang terjadi justru dipandang sebagai potensi untuk meningkatkan semangat keberjamaahan yang makin terorganisir, menjadikan eksis gerakannya dengan atau tanpa atribut-atribut komunitasnya; (3) adanya pola gerakan akomodatif, berkontribusi positif terhadap stabilitas Negara dan mengembangkan kegiatan kemanusiaan; serta (4) adanya kemampuan mengorientasikan gerakannya melalui mekanisme pemaknaan kembali terhadap keyakinannya, sehingga terbuka ruang akomodatif yang cukup signifikan. Melaui proses penyesuaian tindakan sosial tersebut, ketahanan JAI sebagai organisasi justru menguat. Kajian ini memberikan dukungan yang kuat pada teori interaksi inklusif sebagai pranata relasional dalam masyarakat sipil atau tatanan masyarakat beradab.
\end{abstract}

\begin{abstract}
This article reveals the marginalization of Jemaat Ahmadiyah Indonesia (JAI) or Qadiyani Ahmadiyah in Indonesia and adjustment of social action, especially during the reign of the reform era. JAI social action adjustment is indicated by a series of reality, namely: (1) basic solid belief in distress situations though never make existence weakened; (2) the exclusion of that happening is seen as the potential to increase the spirit of congregation more organized, making the movements exist with or without the attributes of the community; (3) the existence of accommodating movement patterns, contributing positively to the stability of the State and to develop humanitarian activities; and (4) their ability to orient its movement through the mechanism of purport back to his faith, so that open to the more significant accommodating space.Throughthe process ofadjustment ofthesocialaction, JAIresilienceas an organizationhas strengthened.This study provides strong support to the theory of inclusive interaction as relational institutions in civil society or order of a civilized society.
\end{abstract}

Kata Kunci: peminggiran, ahmadiyah, gerakan akomodatif, ketahanan, dan interaksi inklusif 


\section{A. Pendahuluan}

Artikel ini mengungkap fakta-fakta peminggiran Jemaat Ahmadiyah Indonesia (JAI) dan penyesuaian tindakan sosialnya dengan pihak Pemerintah maupun masyarakat Islam pada umunya, untuk mempertahankan eksistensinya di Indonesia. Agar mendapatkan penjelasan sosiologis, JAI yang beraliran Ahmadiyah Qadiyani ini dipandang memenuhi kelayakan sebagai komunitas Islam yang tergolong terpinggirkan. ${ }^{1}$ Hal ini selaras dengan hasil penelitian Budi Sartono, ${ }^{2}$ klaim Ahmadiyah sebagai bagian dari Islam faktanya mendapat pertentangan di berbagai wilayah (dunia dan di Indonesia), termasuk adanya penekanan dari Pemerintah (yang dipresentasikan oleh Kementerian Agama RI) dan organisasi masyarakat Islam lainnya.

Tekanan-tekanan terhadap JAI faktanya terjadi sejak kelahirannya pada tahun 1925, bisa jadi tekanan-tekanan atau ancaman tersebut di masa Pemerintahan reformasi justru dirasakan makin menguat. Lintasan fakta-fakta dinamika peminggiran JAI yang terjadi di era reformasi berdasarkan kajian Wawan H. Purwanto, ${ }^{3}$ juga diperlihatkan oleh studi Bernhard Platzdasch, ${ }^{4}$ menyimpulkan bahwa peran pemerintah dan pemimpin organisasi Islam tidak cukup efektif menekan terjadinya kekerasan di berbagai wilayah. Berdasarkan studi Hasbullah Sastrawi ${ }^{5}$, dapat diidentifikasi fakta-fakta intoleransi terhadap JAI dengan mengacu indikator UNESCO berikut ini :

1. Bahasa; Anggota JAI berulang kali mengalami kekerasanverbal dalamberbagai bentukdan kesempatan. Kekerasan verbal tersebut dilakukan olehindividu, kelompok, dan pejabat publik.

2. Stereotip; Prasangka subyektif terhadap pengikut Ahmadiyah terjadi melalui penyesatan dan berbagai tuduhan lainnya. Hal ini dilakukan oleh individu, kelompok, dan pejabat publik dengan cara menyindirpada perilaku, atribut dan karakteristik tertentu. Sindiran yang bersifat ejekan dan hinaan timbul karena prasangka buruk subyektif.

3. Prasangka; Perbedaan-perbedaan sebagian keyakinan Ahmadiyah menjadi instrumen generalisasi negatif.

\footnotetext{
${ }^{1}$ Dimaknai terpinggirkan bilamana kondisi organisasi komunitas memiliki kuantitas anggota yang relatif kecil, cenderung eksklusif secara ideologis, biasanya memperoleh perlakuan intimidatif dari organisasi komunitas yang lebih besar, masyarakat maupun pemerintah, lihat T.K. Oommens, Nation, Civil Society and Social Movement : essays in politic sociology (New Delhi : Sage Publications, 2004).

${ }^{2}$ Budi Sartono, "Diskresi Kapolres Bogor dalam Penutupan Kampus Ahmadiyah di Parung Bogor” (Jakarta : Program Pascasarjana UI, 2007) : Lihat kesimpulan Tesis.

${ }^{3}$ Wawan H. Purwanto, Menusuk Ahmadiyah (Jakarta : CMB Press, 2008), 254 - 264.

${ }^{4}$ Bernhard Platzdasch, "Religious Freedom in Indonesia : The Case of the Ahmadiyah”, Politics \& Security Series, No. 2 (2011) : 1-2.

5 Hasibullah Sastrawi, Ahmadiyah dan Keindonesiaan Komunitas (Jakarta : Pustaka Masyarakat Setara, 2011), 165-170.
}

52 I INDO-ISLAMIKA, Volume 2, Nomor 2, 2015/1437 
4. Pengkambinghitaman; Setiap kekerasan yang menimpa pengikut Ahmadiyah selalu beralasan JAI yang terus menyebarkan keyakinan atau melanggar undang-undang; atau seolah menjadi korban JAI dalam berbagai peristiwa.

5. Diskriminasi; Anggota JAI kehilangan hak-hak sipilnya hanya karena dianggap sesat. Di banyak tempat, pengikut Ahmadiyah tidak diperbolehkan membuat kartu identitas yang memangkas seluruh akses pada hak-hak pelayanan publik lainnya.

6. Pengasingan; Gagasan pengasingan muncul di NTB, yang mana gubernur setempat merencanakan pemindahan pengikut Ahmadiyah ke sebuah pulau. Gagasan yang sama muncul dari Anggota DPR RI dari Komisi VIII, H. M. Busyro.

7. Pelecehan; Intimidasi yang merendahkan dialami anggota JAI hampir di semua tempat.

8. Penajisan dan Penghapusan; Penodaan terhadapsimbol-simbolkesucian keyakinandan perilakukeagamaan penganut Ahmadiyahterjadi dalam bentukperusakan tempatibadah.

9. Gertakan; Gertakan mewujud dalam bentuk desakan bertubi-tubi terhadap JAI agar membubarkan diri dan pengikutnya pindah keyakinan.

10. Pengusiran; Di beberapa tempat terjadi pengusiran dan pemangkasan akses ekonomi (di NTB) dan dunia kerja (di Garut).

11. Pengeluaran; Dalam banyak kasus,sekalipun anggota JAImemiliki aksesterbatas, namun merekamasih mampumemenuhi kebutuhandasar. Bahkan dalam kegiatan PEMILU mereka menjadi bagian yang dimobilisasi, meski tidak punya KTP (di NTB). Namun demikian kemungkinan penyangkalan ini tetap terbuka.

12. Pemisahan; Pemisahan secara massal masih menjadi wacana, namun gejala pemisahan nyata dengan memberi tanda khusus pada rumah anggota JAI terjadi di beberapa tempat.

13. Tekanan; Tekanan masyarakat dan negara yang mendesak anggota JAI untuk menanggalkan kepercayaannya, termasuk pembatasan-pembatasan dalam SKB.

14. Penghancuran; Secara kumulatifunsur penghancuranbelum terjadi, tetapiletupan kekerasanfisik dan pembunuhansudah terjadi.

Merujuk 14 (empat belas) indikator gejala-gejala intoleransi di atas, terdapat 13 (tiga belas) indikator tipologi peristiwa menghimpit JAI, menuju 
penghancuran. ${ }^{6}$ Berdasarkan studi tersebut dapat diidentifikasi realitas intoleransi terhadap JAI, yang menorehkan peminggiran JAI pada pemerintahan era reformasi sebagai realitas yang cenderung makin menguat dari masa ke masa. Hal ini memperkuat fakta peminggiran JAI, dimana eksistensi JAI pada era reformasi vis a vis kekuasaan Pemerintah dan kekuatan organisasi muslim yang menolak keberadaan JAI. Implikasinya, JAI mengalami kooptasi yang signifikan, yang benar-benar membatasi ruang gerak pengurus dan anggota JAI untuk mengekspresikan berbagai kegiatan dakwahnya.

Untuk itu, kajian ini memfokuskan pembahasannya pada 2 (dua) aspek persoalan, yaitu : (1) ketahanan JAI terhadap tekanan-tekanan yang menguat dari pemerintah maupun masyarakat Islam pada umumnya; dan (2) konstruksi interaksi adaptif JAI terhadap negara dan kekuatan masyarakat lainnya di Indonesia.Analisis berbasis pada sumber primer dinamika gerakan organisasi Jemaat Ahmadiyah Indonesia (JAI), khususnya pada masa pemerintahan era reformasi, ditunjang data-data hasil wawancara mendalam dengan beberapa informan kunci, yakni representasi aktivis JAI di Pengurus Pusat dan Cabang, serta dokumen hasil dialogis para pihak terkait persoalan JAI.

\section{B. Kenyataan Peminggiran JAI}

Sejak dikeluarkannya fatwa sesat oleh MUI (Majelis Ulama Indonesia) atas Jemaat Ahmadiyah Indonesia (JAI), ${ }^{7}$ maka JAI menjadi pesakitan yang seolah-olah tidak layak hidup di negeri ini. Bahkan, sumbangan positif Jemaat Ahmadiyah Indonesiapun tidak dihitung, serta merta bermunculnya pelbagai tindakan kekerasan terhadap komunitas Jamaah Ahmadiyah Indonesia. Fatwa MUI oleh publik Islam dianggap sebagai fatwa "menghalalkan" tindak kekerasan pada Jemaat Ahmadiyah Indonesia, maka meski pihak MUI menyatakan tidak boleh terjadi kekerasan atas Ahmadiyah namun bukti-bukti di lapangan seperti dialami JAI Kayumanis Jawa Barat, Kampus Al-Mubarok di Parung Bogor, JAI di Mataram Nusa Tenggara Barat adalah sebuah realitas yang

\footnotetext{
${ }^{6}$ UNESCO, Tolerance : The Threshold of Peace. A Teaching/learning Guide for Education for Peace, Human Rights and Democracy (preliminary version) (Paris : UNESCO.1994, p. 16.), dikutip dari Hasibullah Sastrawi, Ahmadiyah dan Ke-indonesiaan Komunitas (Jakarta : Pustaka Masyarakat Setara, 2011), 165.

${ }^{7}$ Fatwa tersebut pada awalnya dinyatakan MUI tahun 1980, yang menyatakan bahwa Ahmadiyah adalah sebuah aliran sesat yang berada di luar Islam; selanjutnya pada Juli 2005, MUI kembali mengeluarkan fatwa yang menyatakan bahwa Ahmadiyah itu sesat dan para pengikutnya murtad. Lihat pula hasil penelitian M. C. Ricklefs, Mengislamkan Jawa : Sejarah Islamisasi di Jawa dan Penentangnya dari 1930 sampai Sekarang (Jakarta : Serambi Ilmu Semesta, 2013), 514515
}

54 I INDO-ISLAMIKA, Volume 2, Nomor 2, 2015/1437 
tidak dapat dilepaskan dari munculnya fatwa sesat MUI atas Jemaat Ahmadiyah Indonesia (JAI). ${ }^{8}$

Dalam percaturan keadaban tentu menjadi tugas berat bagi institusi agama semacam MUI, tatkala memberikan fatwa yang akan berdampak pada terjadinya kekerasan publik, sehingga antar sesama anggota masyarakat terjadi saling bermusuhan, ada yang terpinggirkan, bahkan menjadi dendam, bukan hanya dendam kultural tetapi sekaligus dendam politik. Hal ini sesungguhnya jauh lebih mengerikan ketimbang fenomena aliran-aliran yang dijustifikasi 'sesat', sebab tata kehidupan masyarakat yang saling curiga, dendam, dan permusuhan akan membuat orang dengan mudah memilih tindakan kekerasan atas nama agama tidak terhindarkan. Menjadi kewajaran belaka jika respon JAI terhadap fatwa tersebut menuduh balik bahwa "MUI-lah yang telah melakukan kebathilan". ${ }^{9}$ Dalam konteks interaksi kelembagaan umat Islampun akan menjadi problem yang serius, sejalan dengan eksistensi institusi MUI yang merepresentasikan umat Islam Indonesia. Terkait fatwa sesat pada Ahmadiyah misalnya, apakah Ahmadiyah memiliki daya tawar yang kuat atas kelompokkelompok Islam tertentu yang dengan garang melakukan tindakan kekerasan kepada para pengikut Jemaat Ahmadiyah Indonesia?

Menurut penilaian JAI, respon masyarakat Islam Indonesia terhadap kasus yang dialami JAI, sebagian menerapkan konsepsi toleransi standar ganda, yakni toleransi yang menghargai pluralitas keislaman, tetapi keislaman yang sudah lazim adanya, tidak disesatkan, dan dianggap tidak merisaukan umat Islam. ${ }^{10}$ Sementara pada komunitas lainnya, membuat terobosan pemikiran dan praktik ritual, umat Islam akan dengan gampangnya menyatakan sesat, salah jalan, harus diluruskan, bahkan harus dipertobatkan. ${ }^{11}$ Masyarakat Islam yang terakhir ini, posisinya seolah-olah sama persis dengan Tuhan Yang Maha Kuasa, adil dan bijaksana, seakan-akan lebih Islam ketimbang Nabi Muhammad dan para

\footnotetext{
${ }^{8}$ Hasil wawancara mendalam dan dialog terfokus dengan Buya Syamsir Ali (Mubaligh JAI), Bapak Sidiq (wakil Amir JAI), Bapak Edi Suryo (pengurus JAI Kota Semarang) dan Bapak Wachid (koordinator JAI Irian Jaya) yang dilaksanakan di Parung - Bogor, tanggal 4 Pebruari 2012, dan wawancara mendalam dengan Bapak Ekki (pengurus JAI Kota Bandung) yang dilaksanakan di Masjid Mubarak, Jl. Pahlawan - Bandung pada 3 Maret 2012.

${ }^{9}$ JAI, Penjelaan Jemaat Ahmadiyah Indonesia (Bogor : PB JAI), 1 - 3.

${ }^{10}$ Hasil wawancara mendalam dan dialog terfokus dengan Buya Syamsir Ali (Mubaligh JAI), Bapak Sidiq (wakil Amir JAI), Bapak Edi Suryo (pengurus JAI Kota Semarang) dan Bapak Wachid (koordinator JAI Irian Jaya) yang dilaksanakan di Parung - Bogor, tanggal 4 Pebruari 2012, dan wawancara mendalam dengan Bapak Ekki (pengurus JAI Kota Bandung) yang dilaksanakan di Masjid Mubarak, Jl. Pahlawan - Bandung pada 3 Maret 2012.

${ }^{11}$ Hasil wawancara mendalam dan dialog terfokus dengan Buya Syamsir Ali (Mubaligh JAI), Bapak Sidiq (wakil Amir JAI), Bapak Edi Suryo (pengurus JAI Kota Semarang) dan Bapak Wachid (koordinator JAI Irian Jaya) yang dilaksanakan di Parung - Bogor, tanggal 4 Pebruari 2012, dan wawancara mendalam dengan Bapak Ekki (pengurus JAI Kota Bandung) yang dilaksanakan di Masjid Mubarak, Jl. Pahlawan - Bandung pada 3 Maret 2012.
} 
sahabat Nabi Muhammad yang disebut sebagai assabiqunal awwalun(orangorang yang awal mula menganut Islam), seperti Abu Bakar As-Sidię, 'Umar bin Khaæab, 'Usman bin Affä̈ dan Ali>bin Abi>Thałib. ${ }^{12}$ Umat Islam Indonesia seakan-akan melampaui derajat kesalehan-nya dari para Nabi dan sahabat sehingga tatkala ada komunitas yang dianggap salah dan sesat, dengan serta merta segera melakukan penggrebekan, perusakan dan pembakaran di samping penganiayaan. MUI dalam konteks semacam itu menjadi sangat lemah kontrolnya sehingga kelompok militan Islam yang rajin membuat ketakutan pada komunitas lain tidak dapat dicegah secara masif.

Di sisi lain, Pemerintah dipandang mengambil langkah yang tegas sejalan dengan mencuatnya kembali kasus JAI di Indonesia pada pasca reformasi, hingga akhirnya dikeluarkannya SKB 3 Menteri, melakukan evaluasi dan solusisolusi yang bisa jadi dipandangnya tepat. Pemerintah RI terus memberikan respon dengan 10 (sepuluh) poin pernyataan resmi yang disampaikan melalui konperensi pers Menteri Agama RI dalam rangka pembukaan Dialog Dengar Pendapat tentang Penanganan Permasalahan Ahmadiyah di Indonesia, ${ }^{13}$ pada 22 Maret 2011sebagaimana berikutini :

1. Pemerintah memahami bahwa JAI terdaftar sebagai Badan Hukum Jemaat Ahmadiyah Indonesia berdasarkan Penetapan Menteri Kehakiman RI Nomor: JA.5/23/13 tanggal 13 Maret 1953 yang dimuat dalam Tambahan Berita Negara Nomor: 26 tanggal 31 Maret 1953. JAI juga terdaftar sebagai organisasi kemasyarakatan di Kementerian Dalam Negeri dengan Nomor: 75/D.I/VI/2003 tanggal 5 Juni 2003;

2. Sikap penolakan juga dilakukan dalam bentuk fatwa yang dikeluarkan oleh MUI pada tahun 1980 menyatakan bahwa Ahmadiyah Qadiyani adalah jemaah di luar Islam, sesat dan menyesatkan, dan pada tahun 2005 yang menyatakan bahwa aliran Ahmadiyah Qodian dan Ahmadiyah Lahore adalah sesat dan menyesatkan. Fatwa yang sama juga dikeluarkan oleh MUI Aceh, MUI Sumatera Utara, MUI Riau, PBNU, Muhammadiyah, dan beberapa organisasi Islam lainnya;

3. Beberapa Pemerintah Daerah melalui Kejaksaan Negeri telah melakukan pelarangan terhadap ajaran Ahmadiyah seperti di Subang, Meulaboh, Lombok Timur, Sindereng Rapang, Kerinci, Tarakan, dan Sumatera Utara.

\footnotetext{
${ }^{12}$ Hasil wawancara mendalam dan dialog terfokus dengan Buya Syamsir Ali (Mubaligh JAI), Bapak Sidiq (wakil Amir JAI), Bapak Edi Suryo (pengurus JAI Kota Semarang) dan Bapak Wachid (koordinator JAI Irian Jaya) yang dilaksanakan di Parung - Bogor, tanggal 4 Pebruari 2012, dan wawancara mendalam dengan Bapak Ekki (pengurus JAI Kota Bandung) yang dilaksanakan di Masjid Mubarak, Jl. Pahlawan - Bandung pada 3 Maret 2012.

${ }^{13}$ Dokumen Notulensi Hasil Dialog dan Dengar Pendapat tentang "Penanganan Permasalahan Ahmadiyah di Indonesia”, bertempat di Kantor Kementerian Agama OR Lt. 3 Jl. MH. Thamrin - Jakarta, tanggal 22 Maret 2011
}

56 I INDO-ISLAMIKA, Volume 2, Nomor 2, 2015/1437 
Bahkan, di beberapa negara ajaran Ahamdiyah juga telah dilarang dikembangkan, seperti di Malaysia, Brunei Darussalam, Pakistan, Kerajaan Arab Saudi, dan oleh Organisasi Islam Internasional - Rabithah Alam Islami;

4. Dalam serial dialog dengan pihak JAI ditawarkan 6(enam) alternatif untuk penyelesaian kasus Ahmadiyah, yakni:

a. Jemaat Ahmadiyah Indonesia (JAI) dibubarkan oleh pemerintah;

b. Jemaat Ahmadiyah Indonesia (JAI) Ahmadiyah dikategorikan sebagai agama di luar Islam;

c. Ahmadiyah diterima oleh umat Islam arus-utama sebagai salah satu aliran dalam Islam;

d. Pemerintah memberi peringatan keras kepada JAI agar menghentikan kegiatannya di seluruh wilayah RI;

e. Diadakan pertemuan/musyawarah antara MUI, JAI, GAI, ormas-ormas Islam dan Pemerintah untuk menyepakati bersama langkah penyelesaian yang harus diambil, dengan prinsip kesediaan saling memahami dan menerima;

f. Ahmadiyah tidak dilarang, tetapi harus menghentikan segala kegiatannya.

5. JAI memilih aternatif, yakni "Ahmadiyah diterima oleh umat Islam arusutama sebagai salah satu aliran dalam Islam";

6. Berdasar pada hasil pemantauan dan evaluasi di lapangan, menurut Pemerintah warga JAI masih menganut penafsiran keagamaan yang menyimpang dari pokok-pokok ajaran Islam, bahkan secara sistematis terus berupaya mengusahakan dukungan umum untuk melakukan kegiatan dan penafsiran keagamaan yang menyimpang melalui buku-buku, dan pengiriman mubaligh-mubalighnya ke daerah-daerah;

7. JAI menyatakan tidak akan mengubah dan tidak ada keinginan untuk merubah kegiatan dan penafsiran keagamaan, dan tidak perlu ada perubahan apapun sebagaimana disampaikan melalui surat dari PB JAI kepada Kementerian Agama, 21 Februari 2008, Nomor: 911/Amir/II/ 2008 dan keterangan Pimpinan PB JAI pada pertemuan dengan kepala Badan Litbang dan Diklat Kementerian Agama tanggal 10 Maret 2008, di Kantor Kementerian Agama;

8. Rapat BAKOR PAKEM (Pengawasan Aliran Kepercayaan Masyarakat dan Keagamaan) pada tanggal 16 April 2008 merekomendasikan kepada Pemerintah untuk mengeluarkan Surat Keputusan Bersama Menteri Agama, Jaksa Agung, dan Menteri Dalam Negeri agar warga JAI diberi 
perintah dan peringatan keras untuk menghentikan penyebaran penafsiran dan kegiatan yang menyimpang dari pokok-pokok ajaran Agama Islam;

9. Pada 9 Juni 2008 akhirnya Pemerintah menerbitkan Surat Keputusan Bersama (SKB) Menteri Agama, Jaksa Agung, dan Menteri Dalam Negeri Nomor: 3 Tahun 2008, Nomor: KEP-033/A/JA/6/2008, Nomor: 199 Tahun 2008 tentang Peringatan dan Perintah kepada Penganut, Anggota, dan/atau Anggota Pengurus Jemaat Ahmadiyah Indonesia dan Warga Masyarakat;

10. Pada tahun 2010 kasus-kasus terkait Ahmadiyah mulai bermunculan lagi dan pada puncaknya pada 2011 ini terjadi kasus bentrokan warga dengan warga JAI di Cikeusik, Pandeglang, yang memakan sejumlah korban. Dalam perkembangannya, kasus ini telah mendorong sejumlah pemerintah daerah di Indonesia untuk mengeluarkan Surat Keputusan yang melarang aktivitas Ahmadiyah di wilayahnya masing-masing.

Melalui "Dialog dan Dengar Pendapat Penanganan Permasalahan Ahmadiyah di Indonesia”, dengan tema : “Mencari Solusi Permanen dan Komprehensif terhadap Permasalahan Ahmadiyah di Indonesia”, yang dilaksanakan dalam 4 (empat) tahap dengan 9 (sembilan) sesi, yaitu pada tanggal 22, 23, 29 dan 30 Maret 2011, ${ }^{14}$ menghasilkan beberapa kesimpulan, yaitu : (1) dalam perspektif Agama Islam, ajaran Ahmadiyah bahwa ajaran tersebut diatas menyimpang dari pokok ajaran Islam; (2) dalam perspektif HAM, solusi menjadikan Ahmadiyah sebagai agama yang berdiri sendiri tidak dapat direkomendasikan dari perspektif HAM, sementara itu pembubaran Ahmadiyah sebagai organisasi dapat dilakukan meskipun pelarangan ajarannya sangat sulit dilakukan kendatipun dalam perspektif hukum pembubaran JAI dimungkinkan; serta perspektif lainnya, diantaranya : perspektif sosial dan psikologi, perspektif politik dalam Negeri dan luar Negeri, perspektif ketertiban umum dan ketentraman masyarakat serta perspektif wawasan kebangsaan.

Realitas respon sebagaimana kronologis di atas, ternyata membuahkan berbagai tekanan-tekanan yang makin kuat di berbagai Provinsi dan Kabupaten/Kota, ditandai dengan kemunculan berbagai Peraturan atau Keputusan Gubernur di beberapa Provinsi maupun Peraturan atau Keputusan Bupati/Walikota di sejumlah Kabupaten/Kota, yang intinya menggambarkan bahwa peminggiran komunitas JAI menjadi makin realistik dan menguat. Realitas tekanan-tekanan atau ancaman terhadap JAI di masa Pemerintahan

\footnotetext{
${ }^{14}$ Pada agenda dialog tersebut faktanya pihak JAI tidak mengirimkan perwakilannya untuk hadir, berdasarkan konfirmasi peneliti ke pihak JAI memberi alasan semata-mata menghindari perdebatan yang tidak setimbang (Hasil wawancara mendalam dengan Buya Syamsir Ali, Mubaligh/Pengurus Besar JAI, dilaksanakan di Parung - Bogor, tanggal 4 Pebruari 2012)
} 
reformasi justru dirasakan makin menguat. Lintasan fakta-fakta dinamika peminggiran JAI yang terjadi di era reformasi berdasarkan analisa Wawan $\mathrm{H}$. Purwanto ${ }^{15}$ terdapat 65 rentetan peristiwa yang terjadi sejak tahun 2000 hingga tahun 2012 yang dapat menjelaskannya. Realitas berbagai peristiwa berbentuk tekanan-tekanan juga diperlihatkan oleh Bernhard Platzdasch. ${ }^{16}$ Menurut catatan Kementerian Agama RI, ${ }^{17}$ terkait dengan eksistensi JAI di Indonesia, sejak kelahiran tahun 1925 menuai penolakan, baik dalam bentuk ungkapan keberatan maupun perusakan terhadap bangunan rumah, masjid dan musholla milik Ahmadiyah di berbagai wilayah di Indonesia (bahkan terjadi pula korban jiwa). Fakta tersebut terjadi di Sumatera Timur (1953), Medan (1964), Cianjur (1968), Kuningan (1969), Nura Tenggara Barat (1976), Kalimantan Tengah (1981), Sulawesi Selatan (1981), Kalimantan Barat, Surabaya dan Bogor (1981), Riau, Palembang, Sumatera Barat, Timor Timur dan Jakarta (1990), Nusa Tenggara Barat (2002), Parung dan Bogor (2006), Kuningan, Majalengka dan Sukabumi (2008), Cikeusik, Banten (2011), serta Tasikmalaya (2012). Menurut Komisi Nasional HAM, fakta-fakta tersebut tidak terlepas dari keluarnya fatwa MUI, sehingga realitas 'kekerasan' atas nama agama terjadi. ${ }^{18}$

Fakta-fakta di atas menggambarkan kuatnya tekanan terhadap JAI, bahkan peran Pemerintah dan Pemimpin Organisasi Islam tidak cukup efektif menekan terjadinya kekerasan di berbagai wilayah. Di sisi yang lain, Pemerintah justru melakukan klaim bahwa akibat kebijakannya, sepanjang tahun 2011 menurut sejumlah berita media massa cukup banyak anggota JAI yang bersyahadat kembali, di antaranya di kecamatan Sangir Sumbar (3 orang), di Tasikmalaya (3 orang), di Cimahi (17 orang), di Sukabumi (18 orang), di Majalengka (11 orang), di Jakarta (70 orang), dikutip dari Media Online Islamedia.com. ${ }^{19}$ Hal ini memperkuat fakta bahwa eksistensi JAI pada era reformasi saat ini secara vertikal (berhadapan dengan kekuasaan Pemerintah) dan secara horisontal (berhadapan dengan kekuatan organisasi muslim yang pro SKB) mengalami kooptasi yang signifikan, yang benar-benar membatasi ruang gerak pengurus dan anggota JAI untuk mengekspresikan berbagai kegiatan

\footnotetext{
${ }^{15}$ Wawan H. Purwanto, Menusuk Ahmadiyah (Jakarta : CMB Press, 2008), 254 - 264.

${ }^{16}$ Bernhard Platzdasch, "Religious Freedom in Indonesia : The Case of the Ahmadiyah”, Politics \& Security Series, No. 2 (2011) : 1-2.

17 Badan Litbang \& Diklat Kementerian Agama RI, Buku Sosialisasi Surat Keputusan Bersama Menteri Agama, Jaksa Agung dan Menteri Dalam Negeri RI, Nomor : 3 Tahun 2008, Nomor : KEP-033/A/JA/6/2008, Nomor : 199 Tahun 2008, tentangPeringatan dan Perintah kepada Penganut Anggota, dan/atau Anggota Pengurus Jemaat Ahmadiyah Indonesia (JAI) dan Warga Masyarakat (Jakarta : Badan Litbang \& Diklat Kementerian Agama RI, 2011), 86.

${ }^{18}$ Luthfi Assyaukanie, “Fatwa and Violence in Indonesia”, Journal of Religion \& Society, Volume 11 (2009) : 7-12.

${ }^{19}$ Wawan H. Purwanto, Menusuk Ahmadiyah (Jakarta : CMB Press, 2008), 254 - 264.
} 
dakwahnya. Pada era Reformasi, berdasarkan catatan sejarah $\mathrm{JAI}^{20}$, realitas eksistensi JAI makin menguat ditandai dengan berkembangnya jumlah Cabang JAI telah mencapai lebih dari 228 cabang wilayah dakwahnya dan semakin banyak muslim yang berbai'at (diperkirakan jumlah anggota JAI di Indonesia saat ini mencapai 500 ribuan orang). ${ }^{21}$ Fakta adanya jumlah cabang JAI dan yang berbai'at mengindikasikan bahwa proses dakwah JAI tetap berjalan dan fakta penyikapan JAI terhadap SKB yang menempuh jalur hukum memberikan indikasi konsistensinya dengan model respon yang berbasis pada kesadaran akomodatif dan intelektual rasional obyektif.

\section{Ketahanan JAI dalam Situasi Peminggiran}

Berdasarkan studi terdahulu, setidaknya terdapat 4 (empat) dimensi ketahanan JAI dalam situasi peminggiranyang dapat dijelaskan menurut struktur tindakan sosial, ${ }^{22}$ yaitu :

Pertama, adanya daya spiritualitas kejuangan JAI sebagai dasar tindakan sosial. Hal ini diindikasikan oleh daya kepribadian Ahmadisebagai motif sekaligus orientasi untuk menguatkan ketahanannya dalam menghadapi berbagai tekanan-tekanan maupun ancaman. Realitas kepribadian tersebut, diinspirasi dari 10 syarat bai'at yang berlaku bagi setiap anggota JAI. ${ }^{23}$ Ini yang

20 JAI, Bunga Rampai Sejarah Jemaat Ahmadiyah Indonesia (1925-2000) (Bogor : Sekretariat JAI, 2000), $200-205$.

21 JAI, Bunga Rampai Sejarah Jemaat Ahmadiyah Indonesia (1925-2000). (Bogor : Sekretariat JAI, 2000), 172 - 180; menurut keterangan Ekky (pengurus JAI Jabar) angka 500 ribu orang itu kategori anggota yang struktural, sedangkan anggota yang bersifat kultural belum terdata jumlahnya, disampaikan saat dialog di Bandung tanggal 17 Mei 2013. Bandingkan dengan pernyataan Abdul Basith, Amir PB. JAI : "pada tahun 2005 jumlah anggota JAI diperkirakan mencapai 200 ribu yang tersebar di 300 cabang seluruh Indonesia”, The Jakarta Post, 16 Juli 2005.

${ }^{22}$ Lihat Catur Wahyudi, Marjinalisasi JAI dan Konstruk Keberadaban Civil Society (LP2M Universitas Negeri Malang : Jurnal Ilmu Sosial, Th. 6 No. 2, Nopember 2014), 80-89

23 Hazrat Imam Mahdi, Masih Mau’ud A.S, Syarat-syarat Bai'at Dalam Jemaat Ahmadiyah, diterjemahkan dari “Isytihar Takmil Tabligh", disajikan dalam lembaran tanpa sumber penerbitan. Sepuluh sarat tersebut adalah (1) senantiasa akan menjauhi syirik; (2) senantiasa menghindari diri dari segala corak bohong, zina, pandangan birahi terhadap bukan muhrim, perbuatan fasiq, kejahatan, aniaya, khianat, mengadakan huru-hara, dan memberontak serta tidak akan dikalahkan oleh hawa nafsunya meskipun bagaimana juga dorongan terhadapnya; (3) senantiasa mendirikan sholat lima waktu semata-mata karena mengikuti perintah Allah dan RasulNya, dan dengan sekuat tenaga akan senantiasa mendirikan sholat tahajud, dan mengirim sholawat kepada Junjungannya Yang Mulia Rasulullah SAW, dan memohon ampun dari kesalahan dan memohon perlindungan dari dosa, akan ingat setiap saat akan nikmat-nikmat Allah, lalu mensyukuri dengan hati tulus, serta memuji dan menjunjung-Nya dengan hati yang penuh kecintaan; (4) tidak akan mendatangkan kesusahan apapun yang tidak pada tempatnya terhadap makhluk Allah umumnya dan kaum muslimin khususnya karena dorongan hawa nafsunya, biar dengan lisan atau dengan tangan atau dengan cara apapun juga; (5) tetap setia terhadap Allah Ta'ala baik dalam segala keadaan susah ataupun senang, dalam suka atau suka, nikmat atau musibah, pendeknya akan rela akan keputusan Allah Ta'ala, dan bersedia menerima segala kehinaan dan kesusahan di jalan Allah, tidak akan memalingkan mukanya dari Allah Ta'ala ketika 
dipahami sebagai keadabansosial Jemaat Ahmadiyah Indonesia (JAI). Terminologi keadaban sosial merupakan bagian pemaknaan masyarakat sipil dalam perspektif budaya. ${ }^{24}$ Dengan demikian, istilah “masyarakat beradab” dapat dipahami sebagai karakter nilai-nilai keadaban sosial, mencerminkan tatanan sosial yang memiliki peradaban ideal (sopan, beretika atau bertata-krama, berbudi bahasa, berakhlaq mulia, saling menghormati atau toleransi, serta memiliki sistem kenegaraan dan sistem ilmu pengetahuan yang maju, yang mampu melahirkan tata cara kehidupan praktis untuk mengatasi persoalan kehidupan). Singkat istilah dapat pula disebut sebagai masyarakat yang berperadaban, berakhlak mulia, mengutamakan musyawarah, saling

ditimpa suatu musibah, bahkan akan terus melangkah ke muka; (6) akan berhenti dari adat yang buruk dan dari menuruti hawa nafsu, dan benar-benar akan menjunjung tinggi perintah Al-Qur'an suci di atas dirinya, firman Allah dan sabda Rasul-Nya itu akan menjadi pedoman baginya dalam tiap langkahnya; (7) meninggalkan takabur dan sombong, akan hidup dengan merendahkan diri, beradat lemah lembut, berbudi pekerti yang halus dan sopan santun; (8) menghargai agama, kehormatan agama dan mencintai Islam lebih daripada jiwanya, hartanya, anak-anaknya, dan dari segala yang dicintainya; (9) selamanya menaruh belas kasih terhadap makhluk Allah umumnya, dan akan sejauh mungkin mendatangkah faedah kepada umat manusia dengan kekuatan dan nikmat yang dianugerahkan Allah Ta'ala kepadanya; dan (10) mengikat tali persaudaraan dengan hamba ini, 'Imam Mahdi dan Al-Masih Al-Mau'ud' semata-mata karena Allah dengan pengakuan taat dalam hal makruf (segala hal yang baik) dan akan berdiri di atas perjanjian ini hingga mautnya, dan menjunjung tinggi ikatan perjanjian ini melebihi ikatan duniawi, baik ikatan keluarga, ikatan persahabatan maupun ikatan kerja.

${ }^{24}$ Istilah civil society diterjemahkan dalam bahasa Indonesia dengan masyarakat sipil atau masyarakat warga atau masyarakat madani. Di antara istilah-istilah tersebut, pemaknaan civility lebih kuat pada pengguna istilah masyarakat madani. Pengertian konsep masyarakat madani menurut Nurcholis Madjid adalah masyarakat berbudi luhur atau berakhlak mulia. Hal ini sejalan dengan pandangan Robert N. Bellah, Beyond Belief (New York : Harper \& Row, 1976), 150-151 : bahwa peradaban yang dibangunan Nabi SAW disebut sebagai masyarakat yang untuk zaman dan tempatnya sangat modern, sehingga setelah Nabi sendiri wafat tidak bertahan lama. Negara di Timur Tengah dan umat manusia saat itu belum siap dengan prasarana sosial yang diperlukan untuk menopang suatu tatanan sosial yang modern sebagaimana telah dirintis Nabi SAW. Dalam istilah lain juga disebut dengan civility atau keadaban, berasal dari akar kata "adab", secara etimologis merupakan kata serapan bahasa Arab, yang berarti sopan santun, budi pekerti atau tata cara, seperti misalnya $a l-A d a>b$ al-Ma $>$ idah yang diartikan tata perilaku atau kesopanan dalam meja makan, lihat Hans Wehr, Mu'jam al-Lughah al-Arabiyah al-Mu'asharah (A dictionary of Modren Written Arabic), Editor : J. Milton Cowan (London : Macdonald \& Evans LTD, 1996), 9; Lihat juga Abdul Mujib dan Yusuf Mudzakir, Ilmu Pendidikan Islam (Jakarta : Predana Media, 2006), 10. Penelusuran sejarahwan M. Abdul Karim terkait istilah adab, bisa jadi berasal dari bahasa jawa kawi, peranakan bahasa sansekerta, yang ucapannya adob, yang memiliki kandungan arti kesopanan, hormat menghormati, berbudi bahasa, etiket, dan sejenisnya, lihat M. Abdul Karim, Sejarah Pemikiran dan Peradaban Islam (Yogyakarta : Pustaka Book Publisher, 2007), 33. Dalam pemikiran Islam, pemaknaan istilah tersebut digali pada era Rasulullah Muhammad SAW saat membangun kota Madinah, antara lain mewariskan karakter keberadaban masyarakat berupa tatanan sosial yang "egaliter, menghargai orang berdasarkan prestasi (bukan atas dasar prestise, keturunan, kesukuan, ras dan sejenisnya), adanya keterbukaan partisipasi seluruh anggota masyarakat, serta prinsip penentuan kepemimpinan melalui proses pemilihan bukan berdasarkan keturunan”, lihat Nurcholis Madjid, "Menuju Masyarakat Madani”, Ulumul Qur'an, Nomor 2 Tahun VII, 5-6; lihat pula Nurcholis Madjid, "The Potential Islamic Doctrinal Resourches for The Establishment and Appreciation of the Modern Concept of Civil Society", Jurnal Paramadhina, Nomer 2 Volume I (Januari, 2002). 
menghormati dan menolong.Kepribadian Ahmadi melandasi langkah-langkah perjuangan Jemaat Ahmadiyah dalam siatuasi dan kondisi apapun yang dihadapi oleh Jemaat Ahmadiyah.Dalam mempraktekkan keyakinannya tersebut, setiap kali eksistensinya didera oleh ancaman, teror, tindakan kekerasan, pengrusakan, atau bahkan pembunuhan, bagi kaum Ahmadi "setiap darah tertumpah di bumi yang diakibatkannya dimaknainya sebagai pupuk dari perjuangan keyakinan kaum Ahmadi untuk mencapai janji Tuhan, jika mereka bisa memenuhi akhlak atau kepribadian Ahmadi”. ${ }^{25}$

Kedua, gerakan JAIbernilai kontributif bagi kemanusiaan. Hal ini dibuktikan melalui adab gerakan kemanusiaan, yang ditunjukkan oleh ciri-ciri organisasi JAI sebagai masyarakat sipil global, yang menonjolkan perilaku berdasarkan pada nilai-nilai permusyawaratan, pengakuan dan penghormatan terhadap hak-hak azasi manusia, serta tata nilai harmoni (yang dikenal dengan “love for all, hatred for none").Daya spiritual seperti diuraikan di atas tidak hanya sebagai dogma, melainkan menjadi bagian dari kesadaran kritis dan modal ketahanan anggota dan pengurus Jemaat Ahmadiyah.Keyakinannya atas Agama Islam yang diperjuangkannya akan benar-benar mencapai kejayaan atas agamaagama lain sebagaimana dijanjikan oleh Tuhan, melalui penegakkan dalil-dalil, kekuatan akal dan pengembangan akhlak kemulyaan. Seluruh proses kejuangan diyakini akan mencapai hasil dengan mengembangkan sistem khilafah menurut tata-cara kenabian sebagaimana ditempuh oleh Jemaat Ahmadiyah yang secara terstruktur merupakan entitas terorganisir dalam manajemen khilafah secara trans-nasional yang terintegrasi ke dalam sistem manajemen khilafah secara internasional. Realitas ini merupakan basis kekuatan JAI dalam budaya atau adabmasyarakat madani, yang menurut pandangan Abu-Nimer (2003), ${ }^{26}$ "komitmen keagamaan semacam itu mendukung keteguhan dan keberanian kepemimpinan nir-kekerasan mereka, bahkan keyakinan terhadap nilai-nilai budaya dan agama tersebut merupakan sarana sangat efektif untuk mengerahkan massa dalam gerakan-gerakan sosial politik”.

Ketiga, setiap konflik direspon JAI melalui dialog dan mubakalah. Realitas ini pernah terjadi, di antaranyaperdebatan antara Pembela Islam (PERSIS) dengan Ahmadiyah yang difasilitasi oleh kelompok netral nasionalis. Pertama kali digelar pada April 1933 membahas persoalan hidup dan matinya Isa AS, kedua pada 28 September 1933 membahas persoalan kenabian dan kebenaran dakwah Mirza Ghulam Ahmad, dan ketiga pada November 1934 yang

\footnotetext{
${ }^{25}$ Hasil wawancara mendalam dengan Buya Syamsir Ali, Mubaligh Pusat JAI, dilaksanakan di Parung - Bogor, tanggal 4 Pebruari 2012.

${ }^{26}$ Mohammed Abu-Nimer, "Nirkekerasan dan Bina Damai dalam Islam”, terjemah : M. Irsyad Rhafsadi \& Rizal Panggabehan : Non Violence and Peace Building in Islam (Jakarta : Alfabet, 2010) , 243-246.
} 
hasilnya justru kaum Ahmadiyah Qadiyani Indonesia sepakat membentukPengurus Besar.Menurut Hans Kung ${ }^{27}$, dialog harus dilakukandemonstratif, yakni mengemukakan pendapat sepanjang-panjangnya sesuai kadar kebenaran yang dimiliki atau dipahami seseorang. Oleh sebab itu, dialog (musyawarah) semestinya tidak mencari kebenaran, melainkan mencari permufakatan masing-masing pihak yang berselisih paham.Fakta-fakta tersebut,memberikan cukup bukti bahwa nilai-nilai fundamental dari suatu gerakan masyarakat sipil pada komunitas terpinggirkan dalam kasus JAI adalah "menjunjung tinggi dialogis permusyawaratan untuk menggali kebenaran atau titik temu”. Meskipun tidak terdapat titik temu, masing-masing pihak yang terlibat dalam perdebatan tetap bersikap obyektif dan toleran. Sudah barang tentu proses-proses semacam itu harus diperantarai dengan mediasi pihak-pihak yang netral. Solusi berikutnya adalah mubałalah yakni masing-masing pihak bersepakat mengambil solusi berhakim kepada Tuhan manakala terjadi kebuntuan atas perbedaan-perbedaan, selanjutnya masing-masing pihak bersikap dengan sabar dan tawakal.

Keempat, pendekatan respon JAI yangmengutamakan caracara akomodatif.Indikasi ini ditunjukkanpendekatan respon JAI yang menonjolkan karakter perilaku, yakni : (1) jika menyangkut perbuatan melawan hukum, maka menempuh mekanisme hukum; (2) jika bentuknya teror, ancaman atau sindiran sinisme, menempuh jalan kehatian-hatian dan tidak memancing emosi pihak lain (menempuh jalan sabar dan tawakal); (3) jika wujudnya pengembangan opini publik, maka menempuh jalan klarifikasi, bahkan mengimbanginya dengan menerbitkan buku untuk menjawab upaya pembentukan opini publik yang juga diterbitkan dalam bentuk buku ${ }^{28}$; serta (4) melakukan kekuatan jejaringnya baik dalam skala nasional maupun internasional dalam sistem khilafahnya, jika menghadapi persoalan yang mengancam eksistensi JAI (baik secara organisional maupun kelompok), yang diakibatkan oleh keputusan atau kebijakan Negara/Pemerintah, kekerasan fisik yang mengancam hak hidupnya.

Dengan demikian, atas dasar kajian tersebut dapat diidentifikasi beberapa faktor penguat ketahanan JAI sebagai komunitasyang terpinggirkan, yaitu : (1)

${ }^{27}$ LIhat Hans Kung, Etika Global (Bandung : Pustaka, 1999).

${ }^{28}$ Beberapa buku yang diterbitkan khusus untuk itu di antaranya adalah : karangan Ahmad Sulaeman \& Ekky, Klarifikasi Terhadap Kesesatan Ahmadiyah dan Plagiator (Bandung : Mubarak Publishing, 2011), merespon karya tulis Hilman Firdaus berjudul "Kesesatan Ahmadiyah" dan karya tulis Prof. Dr. M. Abdurrahman, MA berjudul "Plagiator"; karangan R.H. Munirul Islam Yusuf, Sdd dan Ekky O. Sabandi, Ahamadiyah Menggugat (Bandung : Mubarak Publishing, 2011) dilengkapi kata pengantar dari Prof. Dr. M. Qasim Mathar, MA (Guru Besar UIN Makassar), Zuhairi Misrawi (Moderate Muslim Society) dan Yenny Wahid (The Wahid Institute), merespon buku Dr. Muchlis M. Hanafi, Menggugat Ahmadiyah (Tangerang : Lentera Hati, 2011) yang dilengkapi kata pengantar Prof. Dr. M. Quraish Shihab (Guru Besar UIN Jakarta). 
menguatkan keberadaban illakiyah, (2) menjunjung tinggi perdamaian, (3) mengembangan sikap solidaritas, (4) adab dialogis dan mubałalah, dan (5) akomodatif dengan basis nilai memaafkan adalah utama ${ }^{29}$. Hal ini ditunjang oleh penelitian Winy Trianita ${ }^{30}$, yang menyimpulkan bahwa "pada kalangan perempuan Ahmadiyah, pengorbanan tidak dipahami secara sederhana sebagai praktek seremonial, namun juga bermakna bagi kehidupan mereka, praktek pengorbanan bagi mereka justru menciptakan sebuah ruang untuk mengekspresikan karakter mereka”.

\section{Penyesuaian Tindakan Sosial JAI}

JAI menyadari bahwa langkah-langkah akomodatif menyikapi berbagai fakta peminggiran harus direspon dengan pola-pola siasat bertoleransi, misalnya melalui usaha-usaha dialogis informal, penerbitan buku-buku yang menjelaskan posisi JAI dalam pemahaman kaum JAI sendiri, dialog responsif dan intelektual karya-karya publikasi terhadap yang 'kontra' JAI, serta melalui konsolidasi kerukunan anggota jamaatnya dalam forum-forum silaturahmi komunitas JAI pada tingkatan terkecil, yakni keluarga JAI, hubungan kekerabatan dan ketentanggaan sesama anggota JAI. Bagaimana kekuatan eksistensi semacam ini dapat selalu terpelihara, tentu menjadi tesis yang patut dijelaskan dalam risalah disertasi ini.

Memahami berbagai sumber keyakinan dan ajaran JAI, nampak bahwa kekuatan terbesar yang mempengaruhi eksistensinya JAI merespon persoalannya adalah kuatnya berkepribadian 'Ahmadi', yang menjadi inti keyakinandalam gerakan JAI. Kepribadian tersebut pada dasarnya menjunjung kuat nilai-nilai moralitas dan spiritualitas yang mencakup 3 (tiga) aspek, yakni : (1) aspek keimanan kepada Tuhan Yang Maha Kuasa dengan segala Hak-Hak Kuasa-Nya, sebagaimana diinspirasikan dari risalah “Ajaran-ku” Ghulam Mirza Ahmad; (2) aspek bersosial yang mengutamakan mengalah, memaafkan dan toleransi; serta (3) aspek berkewarga-negaraan sebagai bagian dari bangsa dan Negara tertentu yang diwujudkan dengan kecenderungan kuat tidak melawan terhadap Negara atau Pemerintah kecuali berdasarkan mekanisme hukum yang berlaku.

${ }^{29}$ Nilai spiritualitas ‘memaafkan’ ('afwun) diyakini oleh kaum Ahmadi sebagai esensi dari toleransi dan permakluman atas berbagai perbedaan yang dihadapi dalam kehidupan nyata, Lihat : Mirza Ghulam Ahmad, Islami Ushul Ki Filasafi, diterjemahkan oleh Mukhlis Ilyas : Filsafat Ajaran Islam (Bogor : Sekretariat Isyaat PB. JAI, 2008), 49.

${ }^{30}$ Winny Trianita, "Sacribe” Among Ahmadi Women (Jakarta : Indo Islamika, Jurnal of Islamic Science, Volume 5 Number 1, 2008/1429H), 57.

64 I INDO-ISLAMIKA, Volume 2, Nomor 2, 2015/1437 
Studi Catur Wahyudi, telah mengungkap realitas relasional JAI dengan Pemerintah dan komunitas lainnya dari berbagai rentetan peristiwa selama era reformasi, tersaji pada diagram 1. $^{31}$

\section{Diagram 1 :}

Peta Interaksi JAI dengan Pemerintah dan Komunitas Muslim Lainnya

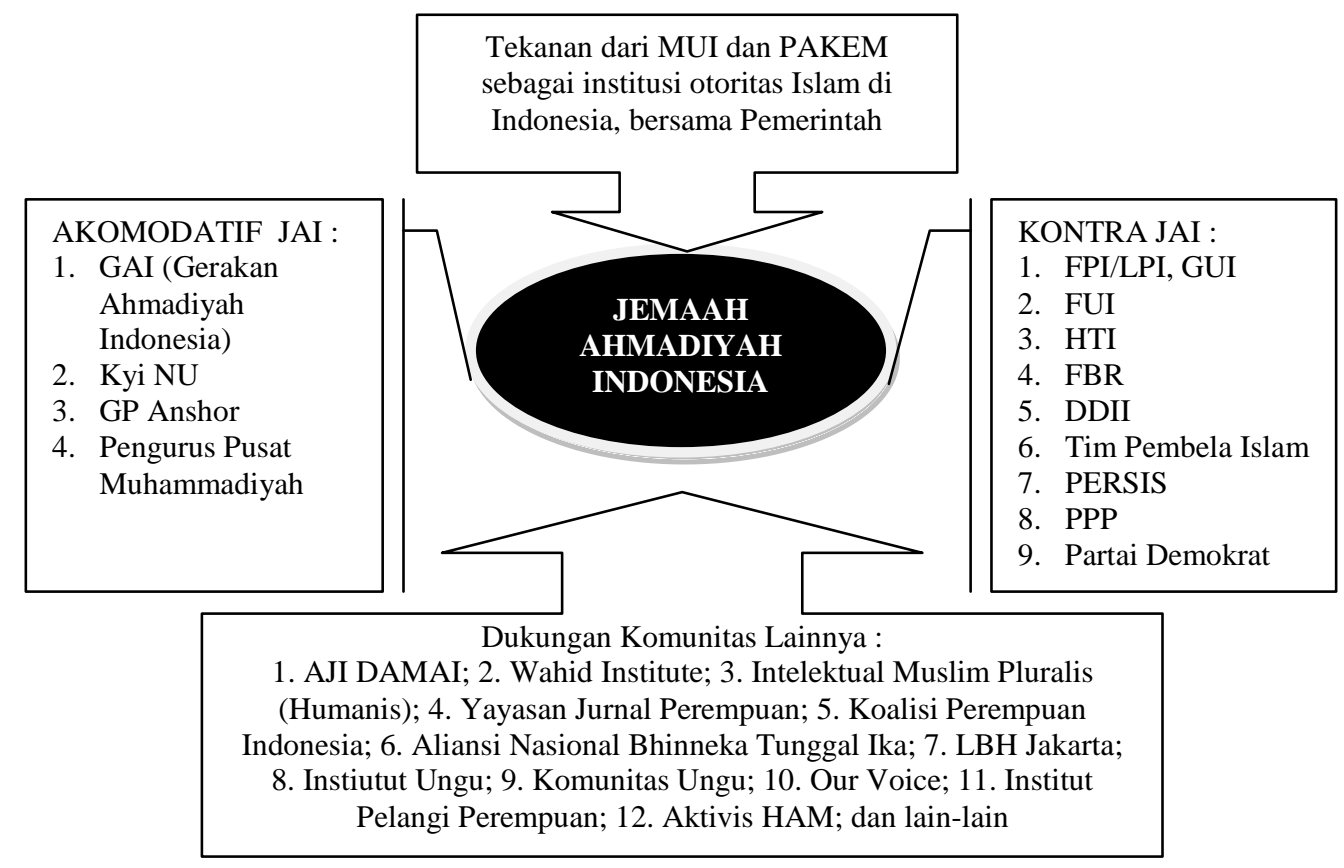

Mencermati realitas relasional tersebut, dapat dikonstruksi beberapa fakta interaksi yang akomodatif, dukungan maupun perbedaan (atau bahkan perlawanan), masing-masing memiliki dasar pemikiran yang dapat dijelaskan secara idelogis dan sosiologis. Hasil studi Reni Susanti, ${ }^{32}$ memberikan suatu kesimpulan bahwa hubungan Negara dan komunitas muslim di Indonesia bukanlah suatu yang sederhana, realitasnya amat dinamis dan kompleks dimensi relasionalnya, bersinggungan dengan aspek-aspek politik, ekonomi dan pasar. Dalam kasus JAI, nampak bahwa energi peminggiran menguat secara signifikan, dilakukan dari unsur Pemerintah yang digerakkan oleh MUI dan Bakor PAKEM, serta unsur Ormas Islam yang secara ideologis berlawanan

${ }^{31}$ Lihat penyajian data dalam disertasi Catur Wahyudi, "Gerakan Civil Society Komunitas Islam Marjinal : Kasus Jemaat Ahmadiyah Indonesia” (Jakarta : Sekolah Pascasarjana UIN Syarif Hidayatullah, 2014), 151.

${ }^{32}$ Reni Susanti, "When Human Rights become So Political : State - Islam Relations and Its Impact on the Ahmadiyya Community in Indonesia, Institute of Social Studi (November 2008) : 2130. 
(konflik) yang didukung oleh Parpol Islam (PPP). Dalam konteks ini, posisi JAI menjadi sub-ordinasi Negara/Pemerintah, kemungkinan ikhtiar yang dapat diusahakan hanyalah 'menasehati Penguasa' jika mengacu pemikiran AlMaærardi $?^{33} \mathrm{JAI}$ dapat pula menguatkan karakter keadaban sosial-nya, mengacu pada pemikiran de Tocqueville yang dianut juga oleh Azyumardi Azra dan Muhammad A.S. Hikam. ${ }^{34}$ Bagi JAI, tidak ada kepantasan 'berontak', sebab "kaum pemberontak dihukumi sebagai bugha» (pelaku kazaliman) yang wajib diperangi", ${ }^{35}$ meskipun faktanya memberikan respon yang amat berani terhadap MUI atas fatwa yang dinilainya sebagai wujud "kebathilan". Bagaimanapun, realitas MUI sebagai alat Negara pada era Orde Baru justru menguntungkan JAI sebab Pemerintah dan rezim yang berkuasa tidak akan menoleransi pecahnya kekerasan sosial yang berpotensi merugikan, menjadi berbeda di saat paska pemerintahan Soeharto dimana MUI justru menjadikan pemerintah sebagai alat MUI. ${ }^{36}$ Faktanya, JAI selalu konsisten untuk memenuhi "kepatuhan" terhadap Negara atau Penguasa yang sah, sebab tidak ingin dicitrakan sebagai kaum pembangkang (pemberontak). Di sisi lain, terdapat kekuatan netral (poros tengah, moderat), yang menyajikan sikap akomodatif dan toleransi meskipun secara ideologis juga terdapat perbedaan, seperti GAI (Gerakan Ahmadiyah Indonesia) kendatipun antara Ahmadiyah Qadiyani (yang dianut oleh JAI) dan Ahmadiyah Lahore (yang dianut GAI) pernah mengalami konflik penafsiran, para Kyi NU, GP Anshor dan PP Muhammadiyah. Adapun potensi yang memberikan kekuatan dari sisi eksternal JAI adalah Aktivis LSM Pluralis dan Nasionalis, itupun terkonsentrasi pada pembelaan yang bernuansa penodaan terhadap HAM semata-mata dalam misi kemanusiaan yang memang sepantasnya dibela.

Fakta-fakta diatas, membuktikan bahwa posisi JAI sebagai komunitas terpinggirkan dalam suatu gerakan keadaban sosialbenar-benar realistik, dan memiliki keberdayaan atau kemandirian yang signifikan untuk menghadapi Pemerintah kendatipun disatu sisi juga memberikan respon "kepatuhan” sebagai strategi menyelamatkan eksistensinya. Realitas penyikapan JAI yang bertahan,

${ }^{33}$ Al-Mawardi, al-ahkam al-s\}ult\}aniyah (Beirut : Da>r al-Fikr, tth), 17-18.

${ }^{34}$ Pemikiran tersebut menjadi bagian penting dari civility (keberadaban), lihat Muhammad A.S. Hikam, Demokrasi dan Civil Society (Jakarta : LP3ES, 1996), 3; lihat pula Azyumardi Azra, "Civil Society dan Demokratisasi di Indonesia, Transisi selama dan setelah Presiden Abdul Rahman Wahid”, dalam Burhanudin, Mencari Akar Kultural Civil Society di Indonesia (Jakarta : INCIS, 2003), 61.

${ }^{35}$ Al-Mawardi, al-Ahkam al-S\}ult\}aniyah (Beirut : Da>r al-Fikr, tth), 58-59, lihat pula Ibn Taimiyah, as-Siya>sah as-Shar'iyyah (Riyadh : Wizarah as-Shu'un al-Islamiyah wa al-Auqaf, 1419 H), 68-88.

${ }^{36}$ M. C. Ricklefs, Mengislamkan Jawa : Sejarah Islamisasi di Jawa dan Penentangnya dari 1930 sampai Sekarang (Jakarta : Serambi Ilmu Semesta, 2013), 514-515

66 I INDO-ISLAMIKA, Volume 2, Nomor 2, 2015/1437 
konsisten dan tidak berhenti melakukan kejuangan atas keyakinannya kendatipun 'tanpa atribut', ${ }^{37}$ menurut pandangan Al Makin (2011) ${ }^{38}$ merupakan kepantasan logis dari sudut pandang teologis, historis, etis, normatif, politis, sosiologis, dan filosofis. Pengamatan Al Makin (2011), ${ }^{39}$ dari berbagai survei dan penelitian lapangan, pada masa reformasi justru terjadi kemunduran segi intelektualisme keagamaan, terutama intelektualisme keislamanan.

Tindakan semena-mena, yang tidak bisa dibenarkan menurut agama, etika, atau hukum bermasyarakat, membuat Ahmadiyah, atau sekte lain, ketakutan karena ancaman, teror, dan hujatan, sekalipun itu ditopang dengan lembaga resmi dan mengatasnamakan negara dan rakyat, tidak akan pernah mampu menghentikan gerakan Jemaat Ahmadiyah Indonesia (JAI) sebab kuatnya potensi spiritual yang menjadi dasar keyakinannya, yang ditunjang dengan kesadaran kritis atas keyakinannya tersebut. Dalam beberapa studi tentang gerakan ideologis yang berbasis pada keyakinan agama atau kepercayaan, faktanya tetap eksis dalam kadar tertentu dalam situasi kondisi yang menekan atau terpinggirkan sekalipun, bahkan mengalami pertumbuhan yang makin menguat pada iklim yang reformatif dan pada iklim politik yang makin liberal. ${ }^{40}$

Berdasarkan uraian fakta-fakta di atas, penjelasan sosiologis interaksi adaptif JAI dalam situasi peminggiran dapat digambarkan dalam kerangka teori fungsional struktural dari Talcot Parsons, ${ }^{41}$ yang mengedepankan 4 (empat) fungsi penting dalam membangun sistem tindakan (perilaku) sehingga eksistensinya akan tetap bertahan, yang dikenal dengan AGIL-theory. Ke-empat fungsi tersebut adalah : (1) Adaptasi, sistem seharusnya mampu menanggulangi situasi eksternal yang mengancam, sehingga diperlukan proses penyesuaian diri dengan lingkungan dan menyesuaikan lingkungan tersebut sesuai kebutuhannya; (2) Pencapaian tujuan, sistem harus mampu mendefinisikan dan mencapai tujuan

37 Semenjak adanya pelarangan melakukan aktivitas-aktivitas sebagai dampak dari SKB 3 Menteri dan Peraturan Gubernur ataupan Peraturan Bupati/Walikota, seluruh atribut Jemaat Ahmadiyah tidak lagi terpampang, satu-satunya atribut yang masih menandainya adalah label kalimah 'la $>$ ilaha ilalla $>h$, muhammadar-rasululla $>h$ ” pada mimbar masjidnya.

38 Al Makin, Jejaring Sutra : Putusnya Satu Benang, Hancurlah Seluruh Sistem, dokumentasi Bahan Dialog \& Dengar Pendapat tentang "Penanganan Permasalahan Ahmadiyah di Indonesia Tahun 2011”, Kementrian Agama RI, Jakarta, 23 Maret, 2011.

39 Al Makin, “Jejaring Sutra : Putusnya Satu Benang, Hancurlah Seluruh Sistem”, dokumentasi Bahan Dialog dan Dengar Pendapat tentang "Penanganan Permasalahan Ahmadiyah di Indonesia Tahun 2011”, Kementrian Agama RI, Jakarta, 23 Maret, 2011, 6-7.

40 As’ad Said Ali, Ideologi Gerakan Pasca Reformasi, Gerakan-gerakan Sosial Politik dalam Tinjauan Ideologis (Jakarta : LP3ES, 2012), viii - xi.

41 Lihat pembahasan penerapan teori AGIL dari Talcot Parsons (Adaptation, Goal attainment, Integration dan Latency) oleh George Ritzer \& Douglas J. Goodman, Teori Sosiologi Modern (Jakarta : Kencana Prenada Media Group, 2008, cetakan ke-5), 121-136 
utamanya; (3) Integrasi, sistem harus memiliki daya dukung pengaturan relasional antar bagian-bagian yang menjadi komponennya; serta (4) Latensi atau pemeliharaan pola, sistem memiliki kelengkapan memelihara dan memperbaiki, mencakup motivasi individu maupun pola-pola kultural yang dapat menguatkan motivasi tersebut. Dengan menggunakan konsep teoritik tersebut, secara empirik dalam kasus JAI, yang faktualnya memiliki daya tahan cukup baik hingga dewasa ini, dapat dijelaskan seperti berikut ini :

Adaptasi secara realistik terdapat dalam organisme perilaku JAI, ditandai dengan respon terhadap tekanan-tekanan dari eksternal diekspresikan melalui usaha-usaha dialogis informal, penerbitan buku-buku yang menjelaskan posisi JAI dalam pemahaman sebenarnya dari JAI sendiri, dialog responsif dan intelektual karya-karya publikasi terhadap yang 'kontra' JAI, serta melalui konsolidasi kerukunan anggota jamaatnya dalam forum-forum silaturahmi komunitas JAI pada tingkatan terkecil, yakni keluarga JAI. Dalam peristiwaperistiwa hukum cenderung menempuh mekanisme hukum yang berlaku dan semaksimalnya memenuhi keputusan Negara, dengan tetap menguatkan hubungan kekerabatan sesama anggota JAI melalui berbagai media "non atribut" (seperti majelis ta'lim ansharullah, pola dakwah berbasis keluarga dan upaya perlindungan terhadap anggota JAI dari ancaman-ancaman).

Pencapaian tujuan secara faktual dapat digali dari sistem kepribadian JAI, ditandai dengan aktualisasi kepribadian Ahmadi yang diinspirasi dari 10 syarat ba'iat, bertumpu pada 3 (tiga) nilai keyakinan JAI sebagaimana telah pula dinyatakan di atas, yakni : (1) aspek keimanan kepada Tuhan Yang Maha Kuasa dengan segala Hak-Hak Kuasa-Nya; (2) aspek bersosial yang mengutamakan mengalah, memaafkan dan toleransi; serta (3) aspek berkewarga-negaraan sebagai bagian dari bangsa dan Negara tertentu yang diwujudkan dengan kecenderungan kuat tidak melawan terhadap Negara kecuali berdasarkan mekanisme hukum yang berlaku. Belakangan kekuatan kepribadian seperti itu dikomitmenkan dengan slogan "love for all, hatred for none”.

Integrasi, faktanya tercermin dalam sistem sosial JAI, yang ditandai oleh kekuatan pranata ekonomi organisasi dengan sistem 'candah' dan ikatan kebersamaan sesama anggota atau organisasi Ahmadiyah Qadiyani dalam skala internasional. Sistem tersebut juga didukung oleh media televisi internasional untuk menguatkan emphati publik, serta posisi tawarnya.Kapasitas organisasinya memadai untuk berkhidmat terhadap Negara atau kekuasaan, dengan menyatakan potensinya sebagai loyalis terhadap Negara sesuai dengan tanggungjawabnya sebagai warga Negara, dengan tetap mengupayakan hak-hak politiknya sebagai bagian dari warga NKRI.Sistem relasional yang mengedepankan proses-proses akomodasi dan toleransi, selalu diutamakan dalam setiap menyikapi perbedaan atau konflik ideologis, dengan tetap 
menjadikan keyakinannya sebagai realitas eksklusif, kendatipun dalam interaksi sosial selalu menguatkan realitas inklusifitas. Inklusifitas dalam interaksi sosial tersebut secara bertahap bergerak menguat pada aspek kemanusiaan- termasuk gerakan peduli sosial, hubungan bisnis (bekerja), serta interaksi “dialogis” berbasis karya-karya publikasi ilmiah sebagai media 'perdebatan' (mujadalah) yang dikemas melalui program bedah buku dan publikasi ilmiah.

Latensi, pemeliharaan pola, secara realistik dapat dilihat berdasarkan sistem kultural JAI sekaligus merupakan norma ideologisnya. Seperti telah dinyatakan pada bagian terdahulu, sistem cultural JAI dibangun dan dikembangkan berdasarkan 2 (dua) keyakinan yang mendasari kaum Ahmadi Indonesia menguatkan motif dan orientasinya sebagai gerakan civil society, yaitu : (1) janji Tuhan yang mengutus Rasul-Nya dengan membawa petunjuk dan agama yang benar, agar "Dia memenangkan Islam atas agama-agama semuanya" (liyudh-hirahu alad-diyni kullihi), dan (2) bahwa masa khulafatur-rasyidin itu terdiri dari 2 (dua) masa : yang pertama adalah masa Khalifah Abu Bakar hingga Khalifah Ali, dan yang kedua adalah dimasa kemudian. Kedua dasar keyakinan tersebut merupakan cita-cita yang melandasi langkah-langkah perjuangan Jemaat Ahmadiyah dalam situasi dan kondisi apapun.Bahkan, "setiap darah tertumpah di bumi yang diakibatkannya, dimaknai sebagai pupuk dari perjuangan keyakinan kaum Ahmadi untuk mencapai janji Tuhan, jika mereka bisa memenuhi akhlak atau kepribadian Ahmadi”.

Sikap JAI secara kejamaatan seperti proses sistemik di atas, merupakan pergumulan besar dalam jiwa Islam menurut ajaran Mirza Ghulam Ahmad. Meskipun demikian, dengan adanya kombinasi antara tekanan komunitas Islam radikal dan Islam pada umunyaserta ancaman-ancaman terhadap Pemerintah, JAI masih selalu berharap munculnya suara-suara baru dalam arus utama kepemimpinan Islam yang menganut suatu 'ijtihad yang baru, yang sesuai dengan modernitas dan hak-hak azasi manusia.Implikasi atas sikap tersebut, JAI dipahami menerima pandangan kaum reformis liberal yang memprioritaskan nilai-nilai inti Islam, yang tersaring dari teks-teks sumber Islam, sebagai normanorma spiritual dan moral yang mengesampingkan penafsiran-penafsiran literal, yang bersifat sosial politis dan memaksa.Tentu saja, bagi JAI amat berkeinginan untuk mengabaikan konsep-konsep tradisional Islam yang acapkali kontradiksi dengan nilai-nilai humanistis modern dari pluralisme, kebebasan dan kesetaraan. Harapan ini selalu menjadi menguatkan spirit untuk berdaya tahan dari berbagai proses peminggiran yang tengah dialaminya. Fakta adanya marginalisasi tersebut ternyata tidak cukup efektif mempengaruhi gerakan dan pertumbuhan JAI, setidaknya eksistensi JAI dengan jamaatnya relatif tidak terpengaruh oleh situasi peminggiran tersebut, sehingga para anggota JAI masih bisa dapat melakukan prosesi ibadatnya dan merawat keberjamaatan para anggotanya menurut 
keyakinannya. Hal ini dapat dibuktikan dengan fakta perkembangan jumlah cabang JAI maupun jumlah anggota yang berbai'at makin bertambah. ${ }^{42}$

\section{E. Penutup}

Beberapa kesimpulan yang dapat dinyatakan sebagai temuan di dalam studi ini adalah realitas peminggiran Jemaat Ahmadiyah Indonesia (JAI) tidak merapuhkan ketahanannya. Ketahanan tersebut dikembangkan melalui beberapa dimensi civility atau adab masyarakat, yaituł (1) spiritualitas kejuangan JAI yang transenden, (2) gerakan kemanusiaan JAI yang dikenal dengan "love for all, hatred for none", (3) gerakan melalui dialog dan mubałalah, serta (4)tindakan JAI yang akomodatif. Dimensi-dimensi ketahanan tersebut dikonstruksi ke dalam interaksi adaptif JAI untuk merespon berbagai tekanan Negara bersama kelompok komunitas yang memberikan dukungan terhadap Negara, faktanya JAI memiliki keberdayaan yang cukup memadai, dibuktikan melalui kontra responnya terhadap MUI dan pertumbuhannya yang masih tetap eksis. Ini berarti, eksisnya nilai-nilai keadaban mampu menjadikan kelompok atau komunitas atau organisasi masyarakat tersebut memiliki 'kekuatan' yang signifikan terhadap Negara maupun terhadap kekuatan kelompok komunitas lainnya

Dalam kasus Jemaat Ahmadiyah Indonesia (JAI) yang memiliki karakter masyarakat sipil global, konstruk interaksi adaptif ditunjukkan dengan realitas bahwa : (1) keyakinan yang kokoh dalam situasi tertekan sekalipun tidak pernah menjadikan eksistensinya melemah; (2) marginalisasi justru dipandang sebagai potensi untuk meningkatkan semangat yang semakin terorganisir, menjadikan eksis gerakannya dengan atau menyamarkan atribut-atribut komunitasnya; (3) adanya pola-pola akomodatif, berkontribusi positif secara konsisten terhadap stabilitas Negara dan mengembangkan kegiatan bertajuk kemanusiaanmerupakan solusi untuk menguatkan eksistensi sebagai komunitas Islam marginal; dan (4) adanya kemampuan mengorientasikan gerakannya bertumpu pada kekuatan soliditas internal komunitasnya melalui mekanisme pemaknaan kembali terhadap keyakinannya sehingga terbuka ruang akomodatif yang cukup signifikan.

42 Data perkembangan sebagaimana telah disajikan pada bab terdahulu juga diperkuat berdasarkan hasil wawancara mendalam dengan Buya Syamsir Ali, Mubaligh/Pengurus Besar JAI, dilaksanakan di Parung - Bogor, tanggal 4 Pebruari 2012; diperkuat pula dari hasil FGD dengan sejumlah aktivis Ahmadi di Kampus Mubarak - Parung pada 4 pebruari 2012; diperkuat dengan wawancara mendalam dengan Sdr. Ekki, pengurus JAI Cabang Bandung, dilaksanakan di Bandung, tanggal 3 Maret 2012; serta klarifikasi melalui Stadium General dengan para santri calon Da’i Jemaat Ahmadiyah Indonesia di Kampus Mubarak - Parung pada bulan Mei 2012. 


\section{Daftar Pustaka}

Abu-Nimer, Mohammed. “Nirkekerasan dan Bina Damai dalam Islam”.terjemah : M. Irsyad Rhafsadi \& Rizal Panggabehan. Non Violence and Peace Building in Islam.Jakarta : Alfabet, 2010.

Abuza, Zachary. Political Islam and Violence in Indonesia. New York : Routledge, 2007.

Ali, As’ad Said. Ideologi Gerakan Pasca Reformasi, Gerakan-gerakan Sosial Politik dalam Tinjauan Ideologis. Jakarta : LP3ES, 2012.

Al Makin.Jejaring Sutra : Putusnya Satu Benang, Hancurlah Seluruh Sistem. Dokumentasi Bahan Dialog \& Dengar Pendapat tentang "Penanganan Permasalahan Ahmadiyah di Indonesia Tahun 2011”.Jakarta : Kementrian Agama RI, 23 Maret, 2011.

Al-Mau’ud, Al-Masihu.“Tazkiratu-sh-Shahadatain”.Majalah Sinar Islam : “50 Tahun Jemaat Ahmadiyah Indonesia”. Nomor Yubillium, Sulh 1355, No. 15 Tahun IV, Januari 1976.

-------. Syarat-syarat Bai'at Dalam Jemaat Ahmadiyah. diterjemahkan dari “Isytihar Takmil Tabligh”, disajikan dalam lembaran tanpa sumber penerbitan.

Al-Mawardi.al-ahkam al-słlltğniyah. Beirut : Daæ al-Fikr, tth.

Assyaukanie, Luthfi. "Fatwa and Violence in Indonesia”.Journal of Religion \& Society, Volume 11, 2009.

Azra, Azyumardi. Menuju Masyarakat Madani : Gagasan, Fakta dan Tantangan. Bandung : PT. Rosdakarya, 1999.

-------. "Civil Society dan Demokratisasi di Indonesia, Transisi selama dan setelah Presiden Abdul Rahman Wahid”. Dalam Buku Burhanudin. Mencari Akar Kultural Civil Society di Indonesia. Jakarta : INCIS, 2003.

Badan Litbang \& Diklat Kementerian Agama RI.Buku Sosialisasi Surat Keputusan Bersama Menteri Agama, Jaksa Agung dan Menteri Dalam Negeri RI, Nomor : 3 Tahun 2008, Nomor : KEP-033/A/JA/6/2008, Nomor : 199 Tahun 2008, tentangPeringatan dan Perintah kepada Penganut Anggota, dan/atau Anggota Pengurus Jemaat Ahmadiyah Indonesia (JAI) dan Warga Masyarakat. Jakarta : Badan Litbang \& Diklat Kementerian Agama RI, 2011.

Barton, Greg. “Kemenangan Civil Society”.editor : Abu Zahar. Politik Demi Tuhan : Nasionalisme Religius di Indonesia. Bandung : PT. Pustaka Hidayah, 2000.

-------. “Issues Concerning Democracy and Citizenship in Indonesia”.in Andrew Vandenberg (ed.). Citizenship and Democracy in a Global Era.Hampshire, London \& New York, USA : Macmillan Press Ltd \& St. Martin's Press Inc., 2000. 
-------. "Political Islam and Violence in Indonesia”.Contemporary Southeast Asia : A Journal of International and Strategic Affairs. Volume 29, Number 2, August 2007.

-------. “Kalau Islam Indonesia Kandas, Bagaimana Negara Lain?”.Hasil wawancara wartawan Madina Online Achmad Rifki dan Irwan Amrizal, pada 21 Januari 2011, www.madina.org, (diakses pada 1 Agustus 2013).

Dokumen Notulensi Hasil Dialog dan Dengar Pendapat tentang "Penanganan Permasalahan Ahmadiyah di Indonesia”, bertempat di Kantor Kementerian Agama OR Lt. 3 Jl. MH. Thamrin - Jakarta, tanggal 22 Maret 2011.

Ghulam Mirza Ahmad. Kisyti Nuh. diterjemahkan oleh : Mirza Bashir Ahmad. “Ajaranku”.Bogor : Yayasan Wisma Damai, 1993.

-------. Islami Ushul Ki Filasafi. diterjemahkan oleh Mukhlis Ilyas. Filsafat Ajaran Islam.Bogor : Sekretariat Isyaat PB. Jemaat Ahmadiyah Indonesia, 2008.

Goffman, Erving.Asylum : Essay on the Social Situation of Mental Patient and Other Inmates. New York : Anchor Books, 1959.

Hanafi, Muchlis M. Menggugat Ahmadiyah. Tangerang : Lentera Hati, 2011.

Hariadi, Ahmad. Mubałalah: Perang Doa Melawan Khalifah Qadiani. Yayasan Kebangkitan Kaum Karim, M. Abdul. Sejarah Pemikiran dan Peradaban Islam. Yogyakarta : Pustaka Book Publisher, 2007.

Hikam, Muhammad A.S. Demokrasi dan Civil Society.Jakarta : LP3ES, 1996.

Ibn Taimiyah. as-Siyasah as-Shar'iyyah. Riyadh : Wizarah as-Shu'un alIslamiyah wa al-Auqaf, $1419 \mathrm{H}$.

JAI.Bunga Rampai Sejarah Jemaat Ahmadiyah Indonesia (1925-2000). Bogor : Sekretariat JAI, 2000.

------. Penjelaan Jemaat Ahmadiyah Indonesia.Bogor : PB JAI.

Kung, Hans. Etika Global.Bandung : Pustaka, 1999.

Lukmantoro, Triyono. "Civil societyDi Bawah Bayang-Bayang Sindrom Praetorianisme”. Makalah disampaikan dalam seminar mahasiswa di Ilmu Komunikasi FISIP Universitas Diponegoro Semarang, Semarang, 1998.

Madjid, Nurcholis. "The Potential Islamic Doctrinal Resourches for The Establishment and Appreciation of the Modern Concept of Civil Society”. Jurnal Paramadhina, Nomer 2 Volume I, Januari, 2002.

------. “Menuju Masyarakat Madani”. Ulumul Qur’an, Nomor 2 Tahun VII.

Mujib, Abdul \& Mudzakir, Yusuf. Ilmu Pendidikan Islam .Jakarta : Predana Media, 2006.

Muntoha dkk, Pemikiran dan Peradaban Islam.Yogyakarta : UII Press, 2002.

Murtolo."Sejarah Singkat Perkembangan Jemaat Ahmadiyah di Indonesia selama 50 Tahun”.Majalah Sinar Islam, Nomor Yubillium, Sulh 1355 Januari 1976. 
Oommens, T.K. Nation, Civil Society and Social Movement : Essays in Politic Sociology. New Delhi : Sage Publications, 2004.

Panikar, Raimundo.Philosophy of Religion.Glancoe, 1999.

Purwanto, Wawan H. Menusuk Ahmadiyah. Jakarta : CMB Press, 2008.

Platzdasch, Bernhard. "Religious Freedom in Indonesia : The Case of the Ahmadiyah”. Politics \& Security Series, No. 2, 2011.

Qodir, Zuly. Sosiologi Agama : Esai-esai Agama di Ruang Publik. Yogyakarta : Pustaka Pelajar, 2011.

Ricklefs, M. C. Mengislamkan Jawa : Sejarah Islamisasi di Jawa dan Penentangnya dari 1930 sampai Sekarang. Jakarta : Serambi Ilmu Semesta, 2013.

Ritzer, George \& Goodman, Douglas J. Teori Sosiologi Modern.Jakarta : Kencana Prenada Media Group, 2008.

Sastrawi, Hasibullah. Ahmadiyah dan Ke-indonesiaan Komunitas.Jakarta : Pustaka Masyarakat Setara, 2011.

Sartono, Budi. “Diskresi Kapolres Bogor dalam Penutupan Kampus Ahmadiyah di Parung Bogor”.Jakarta : Program Pascasarjana UI, 2007

Sidik, H. Munasir. Dasar-dasar Hukum dan Legalitas Jemaat Ahmadiyah Indonesia.Bogor : Jemaat Ahmadiyah Indonesia, 2008.

Sulaiman, Ahmad \& Ekky.Klarifikasi terhadap Kesesatan Ahmadiyah dan Plagiator.Bandung : Mubarak Publishing, 2011.

Susanti, Reni. "When Human Rights become So Political : State - Islam Relations and Its Impact on the Ahmadiyya Community in Indonesia”. Institute of Social Studi. November, 2008.

Thaha, Fawzy Sa’id. Ahmadiyah dalam Persoalan.Jakarta : pt. Alma’arif, 1981.

The Jakarta Post, 16 Juli 2005.

Trianita, Winny. "Sacribe" Among Ahmadi Women.Jakarta : Indo Islamika, Jurnal of Islamic Science, Volume 5 Number 1, 2008/1429H.

UNESCO, Tolerance : The Threshold of Peace. A Teaching/learning Guide for Education for Peace, Human Rights and Democracy (preliminary version). Paris : UNESCO.1994.

Wahyudi, Catur. "Gerakan Civil Society Komunitas Islam Marjinal : Kasus Jemaat Ahmadiyah Indonesia”. Jakarta : Sekolah Pascasarjana UIN Syarif Hidayatullah, 2014.

-------, Marjinalisasi JAI dan Konstruk Keberadaban Civil Society.Malang : LP2M Universitas Negeri Malang : Jurnal Ilmu Sosial, Th. 6 No. 2, Nopember 2014.

Wawan H. Purwanto, Menusuk Ahmadiyah (Jakarta : CMB Press, 2008), 254 264. 
Wehr, Hans. Mu'jam al-Lughah al-Arabiyah al-Mu'asharah( $A$ dictionary of Modren Written Arabic).Editor : J. Milton Cowan. London : Macdonald \& Evans LTD, 1996.

Yusuf, R.H. Munirul Islam \& Sabandi, Ekky O. Ahamadiyah Menggugat. Bandung : Mubarak Publishing, 2011.

Catur Wahyudi, Universitas Merdeka Malang, aturwahyudi_2006@yahoo.co.id 